\title{
Incorporating social justice into the Framework for Information Literacy for Higher Education
}

$\mathbf{T}$ he Framework for Information Literacy for Higher Education was adopted by the ACRL Board in 2016. Many librarians, particularly those interested in critical librarianship and critical information literacy, were disappointed that social justice did not explicitly appear anywhere in the Framework. To be fair, multiple elements of the Information has Value frame describe social justice work, specifically the Knowledge Practice: "understand how and why some individuals or groups of individuals may be underrepresented or systematically marginalized within the systems that produce and disseminate information." ${ }^{1}$

Still, since diversity, equity, inclusion, antiracism, and social justice (EDI) are all important stated values of the library profession, the Framework could be improved. Fortunately, the Framework was intended to be a responsive document that would be updated on a more regular basis than the previous Information Literacy Competency Standards for Higher Education. Although it is only five years old, this column contends that we are overdue in revising the Framework to better incorporate social justice. Without a doubt, other librarians have previously articulated similar sentiments. ${ }^{2}$ The purpose of this column is to extend their arguments with a focus on more recent developments.

\section{Social and racial justice on a national scale}

Five years is barely a blip in higher education, but conversations surrounding social and racial justice, both nationally and within librarianship, have advanced dramatically over this time period. Consider that when the Framework was being created and adopted, Black Lives Matter was still a nascent organization. Rayshard Brooks, George Floyd, Breonna Taylor, Botham Jean, and many more were still with us. The \#MeToo movement had not yet gone viral on a national level. A global pandemic that would sharpen inequality across the globe and put access to healthcare front and center as a social justice issue had not yet hit. Climate justice became more pressing as 2016, 2019, and 2020 all set records for the hottest years on record, while the United States withdrew from the Paris Climate Agreement and rolled back environmental regulations. ${ }^{3}$ Without a doubt, there was national interest and library professional interest in social justice before all these events. What these examples illustrate is a new, more mainstream, national sense of urgency related to social and racial justice.

\section{Bringing the Framework into alignment with current library professional values and strategic goals}

Since the Framework is a national guiding

Christopher Sweet is information literacy and scholarly communications librarian at Illinois Wesleyan University, email: csweet@iwu.edu

๑ 2021 Christopher Sweet 
document adopted by ACRL, it makes sense to review other national and international documents that are important to the library profession for their stance on social justice. A good place to begin this review is with the International Federation of Library Associations (IFLA) Code of Ethics for Librarians (2016) which states,

In order to promote inclusion and eradicate discrimination, librarians and other information workers ensure that the right of accessing information is not denied and that equitable services are provided for everyone whatever their age, citizenship, political belief, physical or mental ability, gender identity, heritage, education, income, immigration and asylum-seeking status, marital status, origin, race, religion or sexual orientation. ${ }^{4}$

This portion of the IFLA Code of Ethics clearly calls for libraries and librarians to engage in social justice work. Speaking more directly to information literacy and social justice, IFLA released a proclamation entitled "Beacons of the Information Society: The Alexandria Proclamation on Information Literacy and Lifelong Learning." This proclamation links information literacy to lifelong learning which "enables individuals, communities and nations . . to meet technological, economic and social challenges, to redress disadvantage and to advance the well being of all." 5 Fundamentally, social justice work is the work of redressing disadvantage. As these two influential documents indicate, social justice is already a priority for the international library profession.

Domestically, there has also been increasing emphasis placed on social justice and librarianship. At the ALA Executive Board Meeting in fall 2018, the Board voted to affirm that ALA will apply a social justice framework to its strategic plan in the following areas: advocacy, information policy, professional and leadership development, and EDI. ${ }^{6}$ Significantly, incorporating social justice into multiple areas of the strategic plan is now an explicitly stated goal for our profession. This clear, recent, directive from the ALA Executive Board should be reason enough to begin the process of updating the Framework to include social justice. Following on the heels of this new strategic plan, the ALA Council also adopted the ALA Core Values of Librarianship in 2019. Speaking again to social justice work, the Core Values state, "The broad social responsibilities of the American Library Association are defined in terms of the contribution that librarianship can make in ameliorating or solving the critical problems of society." ACRL's newly revised (2019) strategic plan, the ACRL Plan for Excellence also includes these components related to social justice:

- Core Commitment: The Association will acknowledge and address historical racial inequities, challenge oppressive systems within academic libraries, value different ways of knowing, and identify and work to eliminate barriers to equitable services, spaces, resources, and scholarship.

- Objective: Support libraries in articulating their role in advancing issues of equity, access, diversity, and inclusion in higher education.

- Objective: Empower libraries to build sustainable, equitable, inclusive, and responsive information literacy programs. ${ }^{8}$

While the ACRL plan clearly describes the work of social justice, like the Framework, it does not explicitly use the term. The goals of this strategic plan (specifically the goal related to information literacy programs) could be leveraged to initiate an update of the Framework.

Taken as a whole, these values statements and strategic plans (all released in the last five years) demonstrate the library profession coalescing around the idea that social justice work is inherently library work.

\section{Barriers to updating the Framework}

Any strategic action, particularly one hoping to enact change within a multifaceted national organization that represents more than 9,000 librarians, requires an unvarnished assessment of potential barriers. Broadly speaking, there 
are barriers that are external to the library profession and then there are those more specific to the profession and the Framework itself.

It will come as no surprise that many segments of higher education in the United States are struggling. In many areas, demographic changes and concerns about student loan debt have resulted in enrollment declines that have forced the closure of some institutions, while many more are facing extreme cuts to budgets and personnel. Throw an extended worldwide pandemic into this volatile mix and it becomes clear why many academic librarians have been focused on literal personal survival and the survival of their institutions rather than updating ACRL documents. The long-term fallout from the COVID-19 pandemic for higher education remains to be seen.

The Framework itself also includes some barriers. As previously noted, social justice as an explicit concept failed to make it into the Framework. This was not for a lack of effort, as a petition to include social justice in the Framework circulated among academic librarians and the results were delivered to the Framework Task Force. ${ }^{9}$ It has been documented that a draft frame entitled Information as a Human Right was considered, but ultimately rejected, by the Framework Task Force. ${ }^{10} \mathrm{~A}$ full rationale for this decision was not shared, but one aspect of the decision was that Task Force members felt social justice was adequately addressed in existing frames and dispositions. The Framework Task Force intended to create a document that would be updated more frequently and easily than the old standards, but an official review schedule or process was never established. While all these barriers may be formidable, they are certainly not insurmountable.

\section{Renewing the Framework}

From the above examples, it is clear that librarianship has made social justice a priority over the last few years. Of course the library profession's prioritization of social justice did not occur in a vacuum. It is both in response to, and in support of, broader national social justice issues, such as racial inequality, criminal justice reform, gender inequality, climate justice, income inequality, and the right to healthcare.

Given the national conversations around social justice and the library profession's recent mandates to advance social justice, it would seem the Framework for Information Literacy is overdue for an update. The appendix to the Framework provides some insight regarding future updates: “. . . the ACRL Board took the official action of 'filing' the Framework document, in accordance with parliamentary procedure. This allows it to be changed without needing Board approval, in order to foster its intended flexibility and development." "11 Most ACRL standards are reviewed and considered for revision on a five year cycle, which indicates the Framework is due for revision in 2021.

The topic of updating the Framework was addressed during the November 2020 ACRL Board Meeting. This portion of the meeting included the ACRL Standards Committee Chair and ACRL Information Literacy Frameworks and Standards Committee Chair who were asked if there were "gaps or issues" with the Framework. These chairs stated that ". . . there has not been recent discussion of major issues with the current Framework." 12

This point is debatable given a rather significant amount of scholarship surrounding various ways the Framework could be improved from the last five years. Given the pressures created by the pandemic and the feedback from the chairs, the ultimate decision from the Board was to postpone the review of the Framework for two more years.

Looking ahead to possible additions to the framework, there is certainly some wisdom in not letting national-level guiding documents become unwieldy over time through continual additions. The Framework, as it stands, is reasonably concise and somewhat comprehensive. Conceptually, there is a great deal of overlap between the frames Research as Inquiry and Searching as Strategic Exploration. It seems like these frames could easily be combined, creating space for a new frame, whether it be Information Social Justice, Information as a Human Right, or some new terminology. 
Professor Laura Saunders has kickstarted the conversation around creating a new social justice frame in her 2017 article "Connecting Information Literacy and Social Justice: Why and How." ${ }^{13}$ Her suggested frame: Information Social Justice, along with proposed Knowledge Practices and Dispositions, helps articulate what a social justice frame might include. Additionally, the original proposal for Information as a Human Right frame could be revisited.

While we are at it, EDI could all be incorporated more intentionally into the current (and any new) frame descriptions, knowledge practices, and dispositions. Perhaps a new frame focused on EDI is warranted, but more than likely EDI, racial justice, and antiracism have a place in each frame.

By the time the 16-year-old Information Literacy Competency Standards for Higher Education were finally replaced by the Framework in 2016, there was general consensus that while the standards did reflect some of the work of librarians, they also presented information literacy in a rather reductive and simplistic fashion. The Framework better positioned information literacy within 21 stcentury higher education pedagogy, theory, and practice.

As this information literacy evolution continues, we should work to ensure that the Framework remains relevant and responsive to the current generation of students.

\section{Notes}

1. ACRL, "Framework for Information Literacy for Higher Education," http://www.ala.org /acrl/standards/ilframework (accessed February 5, 2021).

2. As a starting point regarding other articles written about social justice and the Framework, see Andrew Battista, et al., "Seeking Social Justice in the ACRL Framework," Communications in Information Literacy 9, no. 2 (2015): 111-125, and Laura Saunders, "Connecting Information Literacy and Social Justice: Why and How," Communications in Information Literacy 11, no. 1, (2017): 67.

3. World Meteorological Association, "2020 Was One of Three Warmest Years on Record,” https://public.wmo.int/en/media/press -release/2020-was-one-of-three-warmest-yearsrecord (accessed February 5, 2021).

4. IFLA, "IFLA Code of Ethics for Librarians and Other Information Workers," December 2016, https://www.ifla.org/publications /node/11092 (accessed March 12, 2021).

5. IFLA, "Beacons of the Information Society: The Alexandria Proclamation on Information Literacy and Lifelong Learning," November, 2005, https:/www.ifla.org/publications/beacons-of-the -information-society-the-alexandria-proclamation -on-information-literacy (accessed March 12, 2021).

6. ALA Executive Board, "Action Summary" Fall 2018, http://www.ala.org/aboutala/sites/ala. org.aboutala/files/content/action_items_fa18_0. docx (accessed February 5, 2021).

7. ALA, "Core Values of Librarianship," adopted January 2019, http://www.ala.org /advocacy/intfreedom/corevalues (accessed February 5, 2021).

8. ACRL, "Plan for Excellence," revised November 2019, http://www.ala.org/acrl/aboutacrl /strategicplan/stratplan (accessed February 5, 2021).

9. The author, along with some like-minded colleagues, created and circulated a petition to include social justice in the framework. This petition along with a list of signatories was sent to the Framework Task Force in 2014.

10. Troy Swanson, "Information as a Human Right: A Missing Threshold Concept?” Tame the Web, https://tametheweb.com/2014/07/07 /information-as-a-human-right-a-missing -threshold-concept-by-ttw-contributor-troy -swanson/ (accessed February 5, 2021).

11. ACRL, "Framework for Information Literacy for Higher Education, Appendix 2," http://www.ala.org/acrl/standards /ilframeworkapps\#appendix2 (accessed February 5, 2021).

12. ACRL, "ACRL Fall Board Virtual Proceedings." November 16, 2020. https://connect.ala.org /HigherLogic/System/DownloadDocumentFile . ashx? DocumentFileKey=fb7e 9 cb 1-63b6 -408c-b581-9e09809f38fb (accessed March 29, 2021).

13. Laura Saunders, "Connecting Information Literacy and Social Justice: Why and How," Communications in Information Literacy 11, no. 1, (2017): 67. 2 